\title{
Implementation of Energy Management Concept and Energy Management System in High Rise Office Building
} (Case Study in XXX Building Jakarta)

\author{
Marsul Siregar \\ Departemen Teknik Elektro, Fakultas Teknik, \\ Universitas Katholik Atma Jaya, Jakarta, Indonesia \\ marsul.siregar@atmajaya.ac.id \\ Firma Purbantoro \\ Departemen Teknik Elektro, Fakultas Teknik, \\ Universitas Katholik Atma Jaya, Jakarta, Indonesia \\ purbantoro.firma@gmail.com
}

\begin{abstract}
Energy Management Concept, as part of the Green Building Concept, focuses on improving Energy Efficiency Index (EEI) and Water Consumption Index (WCI). The purpose of this study was to determine how extent the Implementation of green building principles in Office Buildings. The method used is descriptive concerning the Greenship Rating Tools for the existing building. The results show that the Implementation of the Energy Management Concept and System provides energy performance more efficient. The Implementing through Retrofitting of the Chiller Systems, Recycle Waste Water, Replacement of Conventional lamp to Energy Saving LED, and also Training and Education to all employees and tenants. From comparing data research before the Implementation of Energy Management Concept in 2014 and after Implementation and retrofitting in 2016, 2017 \& 2018, respectively. It was found that Energy Efficiency Index (EEI) decreased from 238.8 $\mathrm{kWh} / \mathrm{m} 2 /$ Years to $134,04 \mathrm{kWh} / \mathrm{m} 2 /$ Years and Water Consumption Index (WCI) from 50 liters/person/day to $27.18 \mathrm{Liter} /$ person/Day. And the saving cost of electricity bill payments is IDR. 466,803,325.67 / month (18\%) and roughly will Break-Even Point (BEP) for 3.86 Years
\end{abstract}

Keyword: EMS, Energy Saving, Retrofit, Return on Investment, Energy Management.

\author{
Tajuddin Tan \\ Departemen Teknik Elektro, Fakultas Teknik, \\ Universitas Katholik Atma Jaya, Jakarta, Indonesia \\ tans@atmajaya.ac.id
}

\section{INTRODUCTION}

\subsection{Energy Management Concept}

Energy management is the best solution for direct and immediate reduction of energy consumption. For the last few decades, it has been explored various alternatives to conventional sources of energy like solar, wind, and biomass energy. However, attention must also be given to the best utilization of energy, improvement in energy efficiency, and optimum management of energy resources. In act, energy management deals with existing sources and actual consumption. It includes the planning and operation of energy-related production and consumption units.

The main objectives of energy management are resource conservation, climate protection, and cost savings. The central task of energy management is to reduce costs for the provision of energy in buildings and facilities without compromising work processes. The simplest way to introduce energy management is the effective use of energy to maximize profit by minimizing costs. Energy management could save up to $70 \%$ of the energy consumption in a building or plant. The typical energy saving for any plant or building, using basic energy management principles, could be $10-15 \%$ of the total consumption. This percentage may rose to $25-35 \%$ by a medium scale energy management program (1-3 years)[1]. For achieving a higher degree of savings, a long-term energy management program, spread over for three years or more, is required, which will involve a certain capital investment [1]. The major elements of an energy management program are: to Set the goal of how much energy reduction wants to achieve; to know how much the total consuming; to know the 
significant consumption units and to try to reduce the consumption, and review continuously and report the results to higher management.

The primary objective of energy management is to maximize profit and minimize costs by optimizing energy procurement and utilization, throughout the organization to minimize energy costs without affecting production and quality and to minimize environmental effects. Energy efficiency means using less energy for the same or even increased output. It is increasingly being recognized as one of the most important and costeffective solutions for reducing greenhouse gas (GHG) emissions produced as part of industrial processes. In fact, Energy efficiency has the technical potential to reduce industrial energy use by about $20 \%$ (IEA, 2013). The importance of this potential makes clear when considering that industry today is responsible for $26 \%$ of global CO2 emissions (IEA, 2014a) [4] for $26 \%$ of global CO2 emissions (IEA, 2014a) [4]

\subsection{Energy Management System}

Energy Energy management system (EMS) is a systematic process for continually improving energy performance and maximizing energy savings. An EMS achieves for the company, by establishing a framework for Building facilities to manage their on-going energy use and identify opportunities to adopt energy-saving technologies, including those opportunities that do not necessarily require capital investment.

An EMS helps ensure that energy efficiency improvements do not just happen on a one-time basis, but rather are continuously identified and implemented in the process of constant improvement. Energy management is the key to saving energy, and it is a valuable energy resource that can help meet future energy needs while the nation concurrently develops new and low-carbon energy sources. An EMS can be implemented according to either the available ISO 50001 energy management standard or a custom EMS approach [2]. A key focus of any EMS, regardless of the approach taken, is that it involves all levels and functions of the company and requires the continuous commitment of top management. It ensures the on-going motivation of employees, which is a crucial element in the effective functioning of the EMS framework. As with other recognized management systems (e.g., the ISO 9001 quality standard), an EMS is incorporated into the same management structures as company policy or strategic objectives.

The EMS process is based on the Plan-DoCheck-Act (PDCA) with a continual improvement framework. PDCA framework provides a procedure for companies as; to develop a policy for more efficient use of energy, fix targets and objectives to meet the policy, use data to understand better and make decisions concerning energy use and consumption, measure the results, Review the effectiveness of the policy, and continually improve energy management.

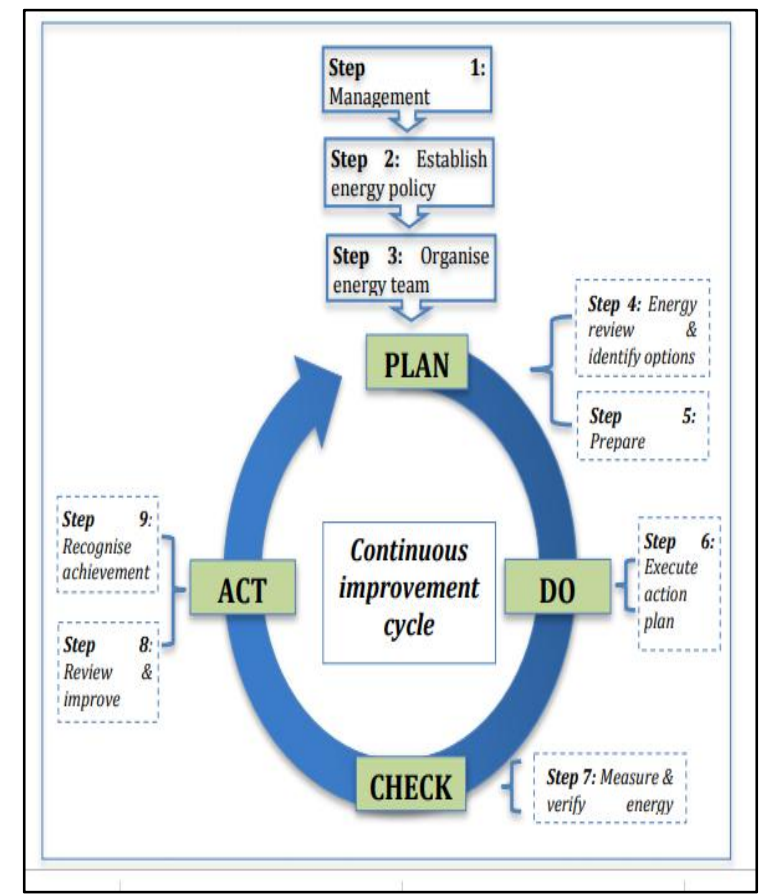

Figure 1.Illustration of the EMS PDCA framework

[4]

Within the PDCA framework, the successful implementation of an EMS depends on a sequence of steps to ensure the process of continuous improvement is achieved (see Figure 1). The critical steps of the process are senior management commitment (Step 1) and having an accurate baseline of energy use (Step 4). No EMS will work effectively without the commitment of senior management. Energy savings are challenging to achieve and verify without having an in-depth understanding of the current energy usage on-site. The following are steps taken for implementation Energy Management Concept, ISO 50001, and Energy Management System; Make a Commitment, Assess Performance, Set Goals, Create Energy Management Action Plan, Implement Energy Management Action Plan, Evaluate Progress, and Recognize Achievements 


\subsection{Green Building Concept}

The concept of Green Building has become popular in the world. Several institutions issue certifications including USGBC LEED [3] [4], Singapore BCA-Green Mark [3] and GBCI [4], this paper takes the certification tool rating from green building council Indonesia (GBCI) for existing buildings. Green Building Council Indonesia (GBC Indonesia) is an independent (non-government) institution that is fully committed to educating of community in applying environmental best practices and facilitating the transformation of a sustainable global building industry [5].

GBC Indonesia has now issued 5(five) types of Greenship, namely: Greenship New Building, Greenship Existing Building, Interior Green Space, Greenship Homes, and Greenship Neighborhoods. Greenship for existing Buildings applied to buildings that have been operating at least one year after construction. The implementation of green buildings in existing buildings is mostly related to the management and maintenance of buildings. This study took the case study of the SSS Building, which is an office building in Jakarta Indonesia that has two towers, each Tower of which has 32 floors and 3 basement floors

The The majority of electricity consumption is from the Ventilating Air Conditioning system 51\%, Lighting System 20\%, Sewage Treatment Plant 9\%, Elevator $8 \%$, Pumps 7\%, Computer, and others 5\%. Greenship Rating Tools for existing Building consist of six categories: Appropriate Site Development (ASD), Energy Efficiency \& Conservation (EEC), Water Conservation (WAC), Resources \& Cycle Materials (MRC), Indoor Air Health \& Comfort (IHC), and Building \& Environment Management (BEM). The award for the existing Building shown in Table 1.

Table 1. Award for existing Building

\begin{tabular}{|c|c|c|}
\hline Rating & Percentage & $\begin{array}{c}\text { Minimum } \\
\text { Point }\end{array}$ \\
\hline Platinium & $73 \%$ & 86 \\
\hline Gold & $57 \%$ & 67 \\
\hline Silver & $46 \%$ & 54 \\
\hline Bronze & $35 \%$ & 41 \\
\hline TOTAL & $100 \%$ & 117 \\
\hline
\end{tabular}

\subsection{Scope of Research}

The scope of this research is to determine how extent the Implementation of green building principles in Office Buildings. The case study in an office building in Jakarta Indonesia has two towers. Each tower has 32 floors and 3 basement floors. The method used is descriptive concerning the Greenship Rating Tools for the existing building. Evaluate the Implementing the Retrofitting of the Chiller Systems, Recycle Waste Water, Replacement of Conventional lamp to Energy Saving LED and also conduct the Training and Education to all employees and tenants.

Comparing the data research before the Implementation of Energy Management Concept in 2014 with the output of the Implementation and retrofitting of 2016, $2017 \& 2018$. Finally, it shows the value of the saving cost during the period time concern of the Water Consumption Index (WCI) and the electricity expenses.

\section{RESEARCH METHOD}

This study was carried out from January 2016 to December 2018 by taking office's building data when obtaining a silver rating and then making efforts to repair (retrofit) the Ventilation Air Conditioning (VAC), Water Recycle and Improving indoor air quality so that in 2017, it can increase the ranking of awards to be platinum and utility report monitoring to calculate Return on Investment (ROI). The research method used is qualitative and quantitative. Qualitative methods [13] were carried out through interviews with the building manager and the consultant team from the Graduate School of Faculty of Engineering Atma Jaya Catholic University of Indonesia, library studies, observation, and documentation. While the quantitative method aims to find relationships or explain the causes of change based on measurable facts based on numerical data, it can be observed and measured.

Flow Chart for this investigation using the block diagram, as shown in Figure. 2, and the Standard Energy Efficiency Index (EEI) of Air Condition rooms for buildings according to the Standard EEI shown in Table 2. The data used in this study consist of primary data and secondary data. Primary data is building planning data from the consultant building planner, Greenship assessment data from GBC Indonesia, and data from direct research obtained by researchers through surveys, interviews, and field measurements. While Secondary data is data collected by other parties that have been documented so that it can be used by other parties (researchers) 


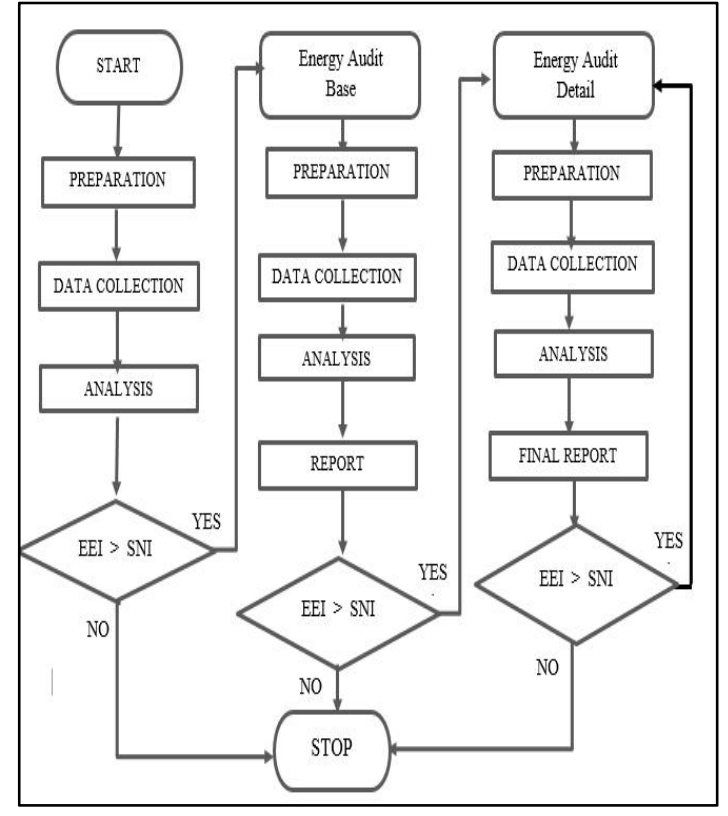

Figure 2. Sequence for data collecting and analysis

Tables 2. EEI of Air Conditioned Rooms for Buildings

\begin{tabular}{|c|l|}
\hline $\begin{array}{c}\text { Efficient } \\
\text { Criteria }\end{array}$ & \multicolumn{1}{c|}{ Explanation } \\
\hline $\begin{array}{c}\text { Very } \\
\text { Efficient } \\
(50-95)\end{array}$ & $\begin{array}{l}\text { Building design complies with the standards of } \\
\text { energy conservation technical planning procedures, } \\
\text { Operation of energy equipment is carried out with } \\
\text { the principles of energy management }\end{array}$ \\
\hline $\begin{array}{c}\text { Efficient } \\
(95-145)\end{array}$ & $\begin{array}{l}\text { Building maintenance and energy equipment is } \\
\text { carried out according to procedures, Efficiency of } \\
\text { energy use is still possible to be improved through } \\
\text { the implementation of an integrated energy }\end{array}$ \\
\hline $\begin{array}{c}\text { Quite } \\
\text { Efficient }\end{array}$ & $\begin{array}{l}\text { The use of energy is quite efficient through the } \\
\text { maintenance of buildings and energy equipment is } \\
\text { still possible, the operation and maintenance of } \\
\text { buildings have not considered the principle of } \\
\text { energy conservation }\end{array}$ \\
\hline $\begin{array}{c}\text { Slightly } \\
\text { Inefficient } \\
(175-285)\end{array}$ & $\begin{array}{l}\text { Energy audits need to be considered to determine } \\
\text { possible efficiency improvements, building design } \\
\text { and maintenance and operation of buildings have } \\
\text { not considered energy conservation }\end{array}$ \\
\hline $\begin{array}{c}\text { Inefficient } \\
(285-350)\end{array}$ & $\begin{array}{l}\text { Energy audit is necessary considered to determine } \\
\text { remedial steps so that energy waste can be avoided, } \\
\text { Equipment installation and operation and } \\
\text { maintenance designs do not refer to energy savings }\end{array}$ \\
\hline $\begin{array}{l}\text { In order to review all energy installations / } \\
\text { equipment and the application of energy } \\
\text { management in building management. Energy audit } \\
\text { is the first step that needs to be done }\end{array}$ \\
\hline
\end{tabular}

\section{REPAIR AND RETROFIT}

The improvement by repair/retrofit consists of Physical infrastructure improvements, i.e., improvements are made to improve the Energy Efficiency Index (EEI) based to the references [6][7][8], and the water consumption index (WCI) and air circulation system to the reference [7]. The Non-physical improvement, i.e., by conducting training and socialization of energy savings to all building employees and tenants. The behavior and habits of all employees and tenants also greatly influence the success of energy-saving programs, for that purpose training is regularly conducted, socialization, and also energy-saving campaigns.

The Item Repair \& Retrofit and its costs are shown in table 3, and the Energy Efficiency Index (EEI) standard for office buildings can be seen in table 4 . One of the objectives of the improvement in the EEI and conservation category is to improve the EEI

The method used is descriptive with respect to Greenship Rating Tools for existing building which consists of six categories; Appropriate Site Development (ASD), Energy Efficiency \& Conservation (EEC), Water Conservation (WAC), Material Resources \& Cycle (MRC), Indoor Air Health \& Comfort (IHC) and Building \& Environments Management (BEM). The ASD Criteria have shown the following Table 5.

Table 3. Item Repair, Retrofit and Cost.

\begin{tabular}{|l|l|c|}
\hline \multicolumn{1}{|c|}{ Item Retrofit } & \multicolumn{1}{c|}{ Category } & \multicolumn{1}{c|}{ Cost (Rp) } \\
\hline $\begin{array}{l}\text { Replacement of 4 Chiller Units (3 } \\
1000 \text { TR Units and } 1 \text { Unit } 500 \text { TR) }\end{array}$ & $\begin{array}{l}\text { Energy } \\
\text { Efficiency \& } \\
\text { Type Screw Compressor with more } \\
\text { energy-efficient centrifugal type }\end{array}$ & 16.577 .000 .000 \\
\hline $\begin{array}{l}\text { Improvements to the wastewater } \\
\text { system so that it can be used for } \\
\text { cooling tower's make up water }\end{array}$ & $\begin{array}{l}\text { Water } \\
\text { Conservation }\end{array}$ & 1.800 .000 .000 \\
\hline $\begin{array}{l}\text { Replacement of conventional lights } \\
\text { with energy-efficient LEDs [6] }\end{array}$ & $\begin{array}{l}\text { Energy } \\
\text { Efficiency \& } \\
\text { Conservation }\end{array}$ & 3.250 .000 .000 \\
\hline TOTAL COST & & 21.627 .000 .000 \\
\hline
\end{tabular}


Table 4. The EEI standard for office buildings

\begin{tabular}{|l|c|c|}
\hline \multicolumn{1}{|c|}{ Sources } & $\begin{array}{c}\text { EEI } \\
\left(\mathrm{kWh} / \mathbf{m}^{2} / \text { Year }\right)\end{array}$ & Years \\
\hline ASEAN-USAID & 240 & 1987 \\
\hline $\begin{array}{l}\text { ESDM \& JICA Electric Power } \\
\text { Development Co Ltd }\end{array}$ & 198,2 & 2008 \\
\hline GBCIndonesia & 250 & 2010 \\
\hline SNI 6196 & 240 & 2000 \\
\hline $\begin{array}{l}\text { Governo's regulation / Pergub } \\
\text { DKI Jakarta No.38 year 2012 } \\
\text { Lentang Bangunan Gedung } \\
\text { Hijau }\end{array}$ & $210-285$ & 2012 \\
\hline
\end{tabular}

Table 5. The ASD Criteria

\begin{tabular}{|c|c|c|c|}
\hline CODE & Criteria & Max Point & Point \\
\hline ASD P1 & Site Management Policy & $P$ & $P$ \\
\hline ASD P2 & Motor Vehicle Reduction Policy & $P$ & $P$ \\
\hline ASD 1 & Community Accessibility & 2 & 2 \\
\hline ASD 2 & Motor Vehicle Reduction & 1 & 0 \\
\hline ASD 3 & Bicycle & 2 & 2 \\
\hline ASD 4 & Site Landscaping & 3 & 3 \\
\hline ASD 5 & Heat Island Effect & 2 & 0 \\
\hline ASD 6 & Storm Water Mannagement & 2 & 0 \\
\hline ASD 7 & Site Managagement & 2 & 2 \\
\hline ASD 8 & $\begin{array}{c}\text { Building Neighbourhood } \\
\text { Recognisance }\end{array}$ & 2 & 2 \\
\hline & Sub Total & 16 & 11 \\
\hline
\end{tabular}

\section{RESULT AND DISCUSSION}

4.1. Energy Efficiency Index (EEI)

EEI data for both towers shown in table 6 below, it is obtained that the average EEI is 134.04 $\mathrm{kWh} / \mathrm{m}^{2} /$ years

\subsection{Water Consumption Index (WCI)}

Recycling results of waste water shown in the building water balance, it is found that an average of $71 \%$ of waste water reused for Make-up water cooling Tower and gardening. Building Population around 16,000 people and average Daily water consumption is $435 \mathrm{~m} 3 /$ days, so the Water Consumption Index (WCI) is 27.18 Liter/person/days.
Table 6. EEI Data for both towers

\begin{tabular}{|c|c|c|}
\hline & South Tower & North Tower \\
\hline Floor & $\begin{array}{c}\text { EEI } \\
(\mathrm{kWW} / \mathrm{m} 2 / \text { Year })\end{array}$ & $\begin{array}{c}\text { EEI } \\
(\mathrm{kWH} / \mathrm{m} 2 / \text { Year })\end{array}$ \\
\hline GF & 300 & 300 \\
\hline 2 & 125 & 125 \\
\hline 3 & 136 & 136 \\
\hline 4 & 126 & 126 \\
\hline 5 & 120 & 120 \\
\hline 6 & 116 & 116 \\
\hline 7 & 119 & 119 \\
\hline 8 & 128 & 128 \\
\hline 9 & 120 & 120 \\
\hline 10 & 137 & 137 \\
\hline 11 & 129 & 129 \\
\hline 12 & 136 & 136 \\
\hline $12 \mathrm{~A}$ & 134 & 134 \\
\hline 14 & 127 & 127 \\
\hline 15 & 124 & 124 \\
\hline 16 & 126 & 126 \\
\hline 17 & 130 & 130 \\
\hline 18 & 134 & 134 \\
\hline 19 & 132 & 132 \\
\hline 20 & 131 & 131 \\
\hline 21 & 115 & 115 \\
\hline 22 & 142 & 142 \\
\hline 23 & 132 & 132 \\
\hline 24 & 117 & 117 \\
\hline 25 & 140 & 140 \\
\hline 26 & 120 & 120 \\
\hline 27 & 125 & 125 \\
\hline 28 & 125 & 125 \\
\hline 29 & 130 & 130 \\
\hline 30 & 300 & 300 \\
\hline 31 & 350 & 350 \\
\hline 32 & 350 & 350 \\
\hline
\end{tabular}

\subsection{Retrofit result}

Retrofit results result observed and focused based on Coefficient of Performances Chiller (COP) and Water Savings as follows:

\subsubsection{Chiller replacement}

Retrofit results may be known from the performance of the chiller efficiency, which can be seen in Fig. 3 and Fig. 4, from the picture it found that the old COP chiller is 3.8 and the new COP chiller is 5.0, or there was an improvement of about $25 \%$. 


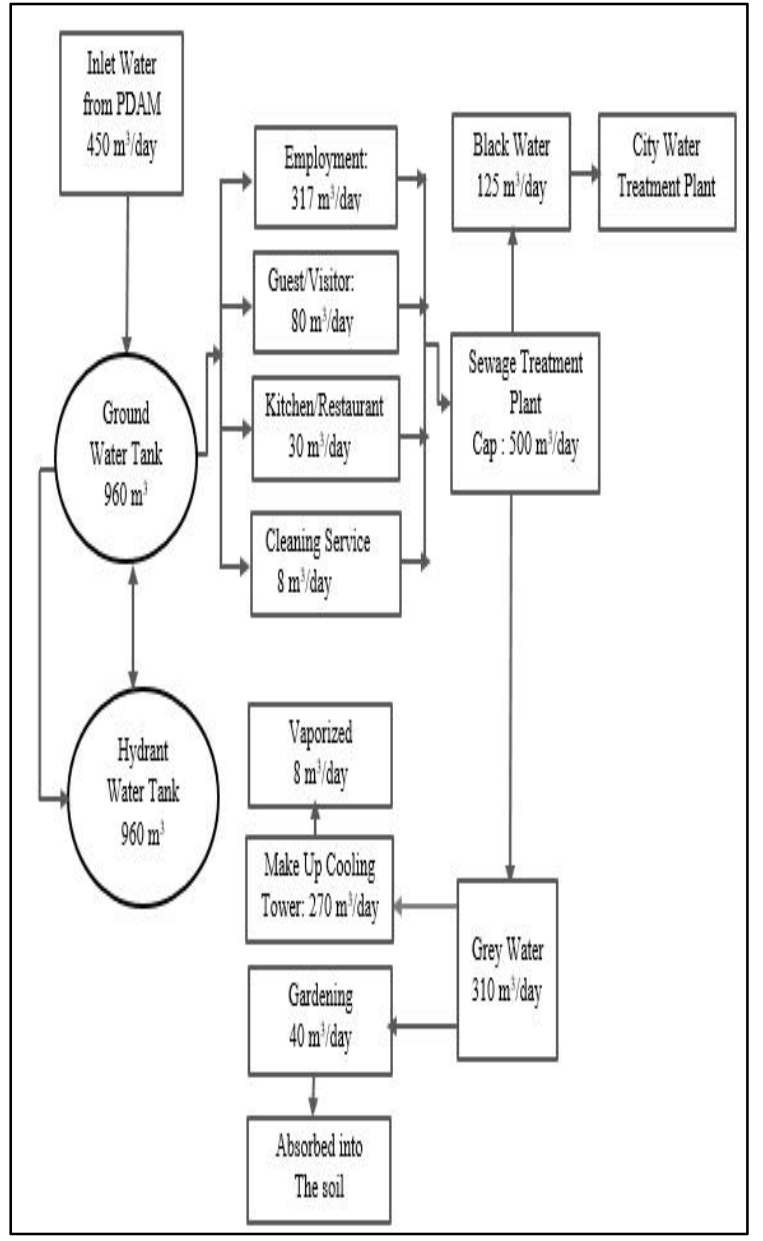

Figure 2. Building Water Balance

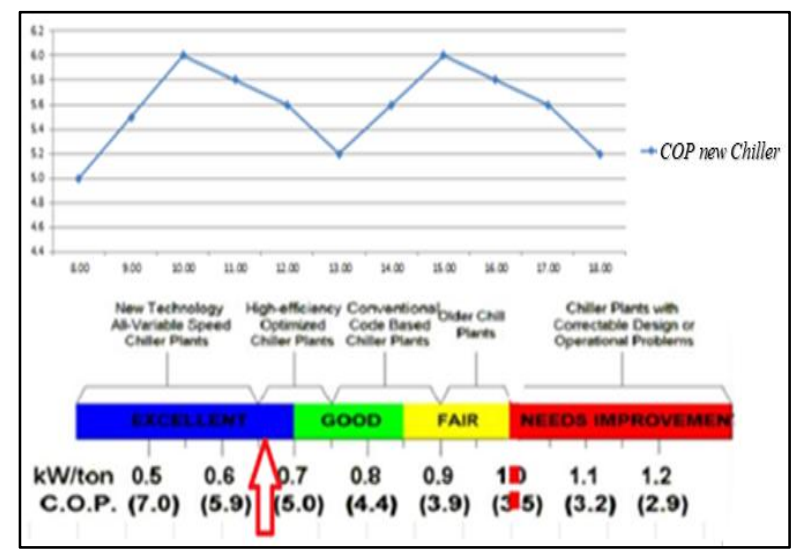

Figure 3. COP of the New chiller

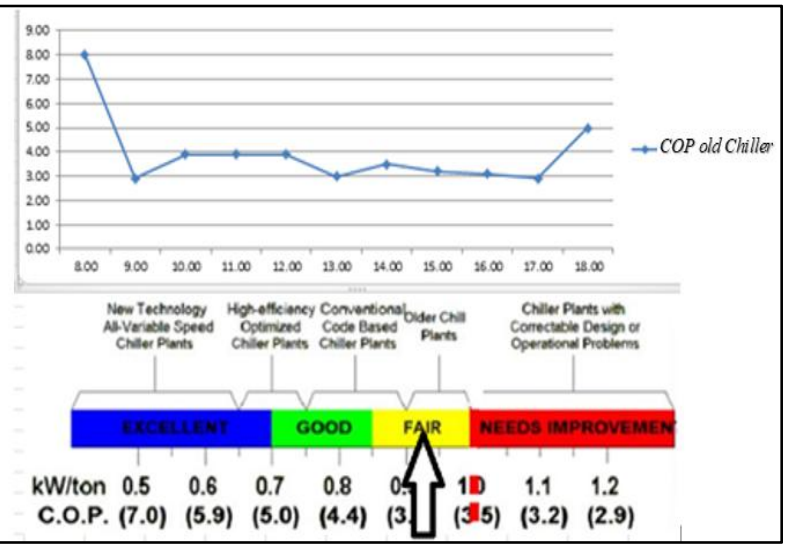

Figure 4. COP of the old chiller

Chiller Efficiency Comparison shown in Table 7 below, from the table it is known that the old Chiller to get a cooling of 1 Ton of Refrigeration (TR) requires energy of $1.63 \mathrm{~kW}$, while for the new Chiller to get a cooling of 1 Ton of Refrigeration (TR) energy is needed at $0.89 \mathrm{~kW}$, meaning that with the new Chiller we get savings of around $50 \%$ compared to the old Chiller.

Table 7. Comparison Efficiency Chiller

\begin{tabular}{|l|c|l|}
\hline & \multicolumn{2}{|c|}{ Efficiency } \\
\hline Chiller Plant & $\begin{array}{c}\text { Old Chiller } \\
(\mathrm{kW} / \mathrm{TR})\end{array}$ & $\begin{array}{c}\text { New Chiller } \\
(\mathrm{kW} / \mathrm{TR})\end{array}$ \\
\hline Chilller A & 0.95 & 0.53 \\
\hline Pompa CHWP(B) & 0.3 & 0.15 \\
\hline Pompa CWP(C) & 0.3 & 0.15 \\
\hline Coolig Tower (D) & 0.08 & 0.04 \\
\hline $\begin{array}{c}\text { Effisiensi System } \\
(\mathrm{A}+\mathrm{B}+\mathrm{C}+\mathrm{D})\end{array}$ & 1.63 & 0.89 \\
\hline
\end{tabular}

\subsubsection{Chiller Electricity Payment Bill after and} Before Retrofit

Electricity bills can be compared before and after the retrofit, the electricity bills before the retrofit shown in Table. 8, while the electricity bills after retrofit in 2017 can be shown in table 9 and table 10 for 2018. On 2018 electricity bills continue to decline due to continued retrofit of conventional lamp replacements with energy-saving lamps (LED), determining ROI using billing data in 2018 . 
Table 8 Payment of electricity bills in 2014

\begin{tabular}{|l|c|c|c|c|c|}
\hline \multirow{2}{*}{\multicolumn{1}{|c|}{ Bulan }} & \multirow{2}{*}{ Tahun } & \multicolumn{2}{c|}{ PLN } & \multirow{2}{*}{ TOTAL } & \multirow{2}{*}{ Rupiah } \\
\cline { 3 - 4 } & & LWBP & WBP & & \\
\hline Januari & 2014 & $1,892,760$ & 307,800 & $2,200,560$ & $2,796,413,194$ \\
\hline Februari & 2014 & $1,912,320$ & 294,480 & $2,206,800$ & $2,459,192,381$ \\
\hline Maret & 2014 & $2,059,440$ & 325,920 & $2,385,360$ & $2,458,753,699$ \\
\hline April & 2014 & $2,046,600$ & 289,320 & $2,335,920$ & $2,590,922,198$ \\
\hline Mei & 2014 & $2,040,120$ & 310,440 & $2,350,560$ & $2,661,675,274$ \\
\hline Juni & 2014 & $2,087,400$ & 306,240 & $2,393,640$ & $2,960,947,907$ \\
\hline Juli & 2014 & $1,902,480$ & 306,240 & $2,208,720$ & $3,007,494,036$ \\
\hline Agustus & 2014 & $2,113,680$ & 321,480 & $2,435,160$ & $2,732,377,851$ \\
\hline September & 2014 & $2,117,760$ & 315,000 & $2,432,760$ & $3,150,719,192$ \\
\hline Oktober & 2014 & $2,190,000$ & 327,600 & $2,517,600$ & $3,065,388,481$ \\
\hline November & 2014 & $2,056,080$ & 320,520 & $2,376,600$ & $3,140,022,359$ \\
\hline Desember & 2014 & $2,059,440$ & 300,360 & $2,359,800$ & $2,966,604,401$ \\
\hline TOTAL & & $24,478,080$ & $3,725,400$ & $28,203,480$ & $33,990,510,973$ \\
\hline Rata-rata & & $2,039,840$ & 310,450 & $2,350,290$ & $2,832,542,581$ \\
\hline
\end{tabular}

Table 9 Payment of electricity bills in 2017

\begin{tabular}{|l|c|c|c|c|}
\hline \multirow{2}{*}{ Months } & \multicolumn{2}{|c|}{$\mathrm{kWH}$} & TOTAL $\mathrm{kWH}$ & Bills (IDR) \\
\cline { 2 - 3 } & LWBP & WBP & & \\
\hline January & $1.862 .240,00$ & $285.480,00$ & $2.147 .720,00$ & $2.435 .420 .435,00$ \\
\hline February & $1.689 .240,00$ & $259.680,00$ & $1.948 .920,00$ & $2.204 .819 .346,00$ \\
\hline March & $1.960 .560,00$ & $294.840,00$ & $2.255 .400,00$ & $2.548 .529 .930,00$ \\
\hline April & $1.759 .200,00$ & $271.800,00$ & $2.031 .000,00$ & $2.298 .304 .042,00$ \\
\hline May & $1.994 .880,00$ & $291.840,00$ & $2.286 .720,00$ & $2.580 .158 .176,00$ \\
\hline June & $1.701 .600,00$ & $262.440,00$ & $1.964 .040,00$ & $2.222 .319 .885,00$ \\
\hline July & $1.986 .120,00$ & $309.360,00$ & $2.295 .480,00$ & $2.598 .740 .566,00$ \\
\hline August & $1.951 .440,00$ & $291.120,00$ & $2.242 .560,00$ & $2.532 .938 .539,00$ \\
\hline September & $1.822 .800,00$ & $288.360,00$ & $2.111 .160,00$ & $2.392 .106 .931,00$ \\
\hline October & $1.962 .720,00$ & $286.920,00$ & $2.249 .640,00$ & $2.538 .220 .521,00$ \\
\hline November & $1.899 .720,00$ & $287.640,00$ & $2.187 .360,00$ & $2.472 .545 .772,00$ \\
\hline December & $1.773 .000,00$ & $283.560,00$ & $2.056 .560,00$ & $2.331 .650 .524,00$ \\
\hline TOTAL & $22.363 .520,00$ & $3.413 .040,00$ & $25.776 .560,00$ & $29.155 .754 .667,00$ \\
\hline Average & $1.863 .626,67$ & $284.420,00$ & $2.148 .046,67$ & $2.429 .646 .222,25$ \\
\hline
\end{tabular}

We found that the average electricity bill per month before the Retrofit is: IDR. 2,832,542,581 for the years 2014, IDR. 2,429,646,222.25 for 2017 and IDR. 2.365.739.255,33 for 2018.

Table 10 Payment of electricity bills in 2018

\begin{tabular}{|l|l|l|l|l|}
\hline \multirow{2}{*}{ Months } & \multicolumn{2}{|c|}{$\mathrm{kWH}$} & \multirow{2}{*}{ TOTAL $\mathrm{kWH}$} & \multirow{2}{*}{ Bills (IDR) } \\
\cline { 2 - 3 } & LWBP & WBP & & \\
\hline January & $1.932 .360,00$ & $283.200,00$ & $2.215 .560,00$ & $2.500 .101 .165,00$ \\
\hline February & $1.688 .400,00$ & $252.840,00$ & $1.941 .240,00$ & $2.193 .040 .256,00$ \\
\hline March & $1.878 .120,00$ & $287.520,00$ & $2.165 .640,00$ & $2.449 .439 .060,00$ \\
\hline April & $1.887 .960,0 \mathrm{p}$ & $286.200,00$ & $2.174 .160,00$ & $2.457 .775 .681,00$ \\
\hline May & $1.839 .600,00$ & $285.480,00$ & $2.125 .080,00$ & $2.405 .337 .702,00$ \\
\hline June & $1.572 .960,00$ & $236.880,00$ & $1.809 .840,00$ & $2.045 .208 .432,00$ \\
\hline July & $1.878 .720,00$ & $275.760,00$ & $2.154 .480,00$ & $2.431 .365 .776,00$ \\
\hline August & $1.840 .080,00$ & $281.160,00$ & $2.121 .240,00$ & $2.398 .973 .869,00$ \\
\hline September & $1.785 .840,00$ & $277.320,00$ & $2.063 .160,00$ & $2.335 .335 .546,00$ \\
\hline October & $1.948 .680,00$ & $278.520,00$ & $2.227 .200,00$ & $2.509 .959 .105,00$ \\
\hline November & $1.818 .480,00$ & $270.960,00$ & $2.089 .440,00$ & $2.359 .836 .300,00$ \\
\hline December & $1.773 .240,00$ & $265.080,00$ & $2.038 .320,00$ & $2.302 .498 .172,00$ \\
\hline TOTAL & $21.844 .440,00$ & $3.280 .920,00$ & $25.125 .360,00$ & $28.388 .871 .064,00$ \\
\hline Average & $1.820 .370,00$ & $273.410,00$ & $2.093 .780,00$ & $2.365 .739 .255,33$ \\
\hline
\end{tabular}

By comparing the payment of electricity bills before and after Retrofit, comparing from Table 8 and Table 10, it found that the difference in electricity payments is IDR. $466.803 .325,67 /$ month

From Table 3 it is found that the retrofit Cost is IDR $21,627,000,000.00$ so the estimated value Return of Investment ROI is (IDR $21,627,000,000 \div$ IDR 466.803.325,67). Then we found that the ROI $=46.33$ months or 3.86 Years.

\section{CONCLUSION AND REMARKS}

Energy management is the process of monitoring, controlling, and conserving energy in a building or an industry. Energy management is the key to saving energy in the organization. Energy management is a vital energy resource that can help meet future energy needs while the nation concurrently develops new and low-carbon energy sources

The concept of green building becoming a global trend when applied will not only strengthen the brand image of the building itself but also save operational costs for building management, in the case study of the SSS building after retrofitting the VAC system by replacing the chiller, Recycle waste water, replace it with Energy Saving lights and also socialize to all employees and tenants, then the savings from payment of electricity bills are only IDR. 466,803,325.67/month (18\%) and return of the capital for 3.86 Years.

High-rise buildings still have much potential for further research by installing renewable energy plants such as the installation of solar power plants (solar cells) [7] by utilizing the roofs or facades of buildings and also utilizing the gravitational potential of clean water systems and VAC systems (micro-hydro power plant).

\section{REFERENCES}

[1] https://new.usgbc.org/ latest accessed on July 6, 2019

[2] Shawn Roy, Prcscott C. Ensign dan Tom Brzustowski, 2016, An assessment of LEED certification's impact on net rental rates for commercial office space in Toronto, Ontario, Portland International Conference on Management of Engineering and Technology (PICMET), Honolulu, HI USA, 4-8 Sept. 2016, Date Added to IEEE Xplore: 05 January 2017

[3]https://www.bca.gov.sg/greenmark/greenmark_b uildings.html, latest accessed on June, 2019

[4] http://gbcindonesia.org/, latest accessed on June, 2019

[5] Governor's Prov DKI Jakarta Regulation No 38, 2012 / Concerning Green Building

[6] Indonesian National Standard ( SNI) No. 61972011 Energy Conservation in the Lighting System,

[7] Pamungkas Dany, Manisa Pipattanasomporn, Saifur Rahman, Nanang Hariyanto, Suwarno, 2018, ICUE 2018 on Green Energy for Sustainable Development Thavorn Palm Beach 
Resort Karon, Phuket, Thailand. $24-26$ October 2018

[8] ISO 50001:2018 Energy Management Systems, The Implementation Guide BSI Group

[9] Indonesian National Standard ( SNI) No 036196-2000, Procedure for auditing energy in buildings.

[10] Technical Guidelines for Energy Audits in Energy Conservation Implementation and reduction of $\mathrm{CO} 2$ emissions in Industrial (phase1) issued by Center for Assessment of Green Industry and the Environment

[11] Guidance to Energy Savings in Government Buildings in accordance with the mandate of the Minister of Energy and Mineral Resources Regulation no. 13 of 2012 concerning the Saving of Electricity.

[12] Dalia M.M. Yacout, Institution of Graduates Study and Research, Alexandria University. Published in http://www.ecomena.org/October 10,2014

[13] Dwipriyoko, E., Bon, A. T. B., \& Sukono, F. (2019), Enterprise Architecture Planning as New Generation Cooperatives Research Methods, Journal of Physics: Conference Series (Vol. 1179, No. 1, p. 012094), IOP Publishing. 